\title{
Entropic estimation of orderliness of transport service of large Russian city in $\mathbf{2 0 2 0}$
}

\author{
Artur Petrov ${ }^{1 *}$ \\ ${ }^{1}$ Tyumen industrial University, 38 Volodarskogo str., Tyumen, 625000, Russia
}

\begin{abstract}
This article presents approaches to estimate orderliness of transport service of large city by means of city passenger public transport (CPPT). An article considers entropic analysis method as main analytical instrument of orderliness of transportation process. Author presents causeand-effect chain of formation of results of transportation process by CPPT and process of informational transformation during transportation. An article gives an example of calculation of relative entropy of transportation process by CPPT in Tyumen during March-September 2020. Additional attention was paid to changes of orderliness of transport service during the acute phase of pandemic COVID-19 (April-June 2020). It was established that relative entropy of transportation process decreased during acute phase of pandemic COVID-19 in comparison to periods of sustainable functioning of CPPT system. Respectively orderliness of transportation process increased at the same time. This fact can be explained by structural changes of volume of transported passengers (total volume of traffic volume of transportation of preferential passengers - volume of transportation of senior citizens). By the results of research author made conclusions and gave recommendations on possible increasing of orderliness of CPPT transportation process.
\end{abstract}

\section{Introduction}

Recent events of $2019 \ldots 2020$ reminds us of continuously increasing significance of social processes orderliness. Control of every sphere of life obtains more priority than other aspects of management. Consequently, research of transport systems' orderliness and orderliness of different transportation processes becomes modern scientific research direction.

Orderliness of transport service of large cities population gain importance these days. Main reasons of this trend are necessity of decrease of production processes randomness, importance of increase of quality of predictions of traffic volume and intention of improvement of transportation process efficiency.

High level of uncertainty of demand for transportation supply and not precise satisfaction of this demand are peculiarities of passengers' transportation. Demand for CPPT service depends on many dynamically changings environmental factors. Main problems of transportation process management are search of instruments that can increase

* Corresponding author: ArtIgPetrov@yandex.ru 
precision of predictions of transportations demand and improve balance between transport service's demand and supply and improvement of methods of estimation of transport service orderliness.

System chaos can be measured by entropic analysis. This instrument can give answers on two main questions:

- What is the final level of structural disorder (antipode of orderliness) in system of provision of high quality of transport service for city population?

- Which resources can increase orderliness of CPPT service?

$\mathrm{N}$. Wiener [1,2] and C. Shannon [3, 4] showed in their works that the main problem of correct system management is necessity of saving the quality of control signal during the process of information transfer in corresponding channels. Information is continuously changing and transforming in spacetime. As a result, informational uncertainty is formed. C. Shannon named it as informational entropy [3, 4]. Entropy characterizes quantitative estimation of information loss during the process of passing it in the channel [3 - 10]. Consequently, entropic analysis is convenient instrument for estimation of quality of production-technological processes management $[11,12,13]$. It can be applied to estimation of quality of passengers' transportations management. We need to remember that entropy is low in highly organized system and high in low-level organized systems. And vice versa negentropy will be high in highly organized system [14, 15].

\section{Purpose and problems of research}

The purpose of research is to determine the level of orderliness of process of transportation service of population of large Russian city Tyumen (population - nearly 810 thousand people) in dynamics and its changing during the process of implementation of managerial decision of introduction of measures for limiting overall and especially transport mobility due to spread of infection COVID-19.

Tasks of research:

1. Collection and analysis of statistics necessary for identification of population mobility and volume of transportations of specific CPPT route.

2. Processing of this information in cybernetic cause-and-effect model $[11,12,13]$.

3. Determination of entropy of transport service process.

4. Identification of entropy dynamics of process of transportation service of Tyumen population during the acute phase of pandemic COVID-19 (1.03.2020..30.06.2020) and postepidemiological period (1.07.2020...30.09.2020).

5. Analysis of results and development of recommendations for increase of orderliness of CPPT transportation process of large city.

\section{Method of the problem solution}

\subsection{Cause-and-effect chain of formation of CPPT transportation process results. Informational transformation process during transport process}

Specific methods of estimation of entropy of human-technological systems in relation to issues of road safety formation and public transport transportation process were considered in works $[11,12,13]$. By using this baseline, cause-and-effect chain of formation of CPPT functioning results can be presented as in fig. 1. This three-units cause-and-effect chain is one of the options of transformation of such significant transport service characteristic as transportations volume. 
1 process link

2 process link

3 process link

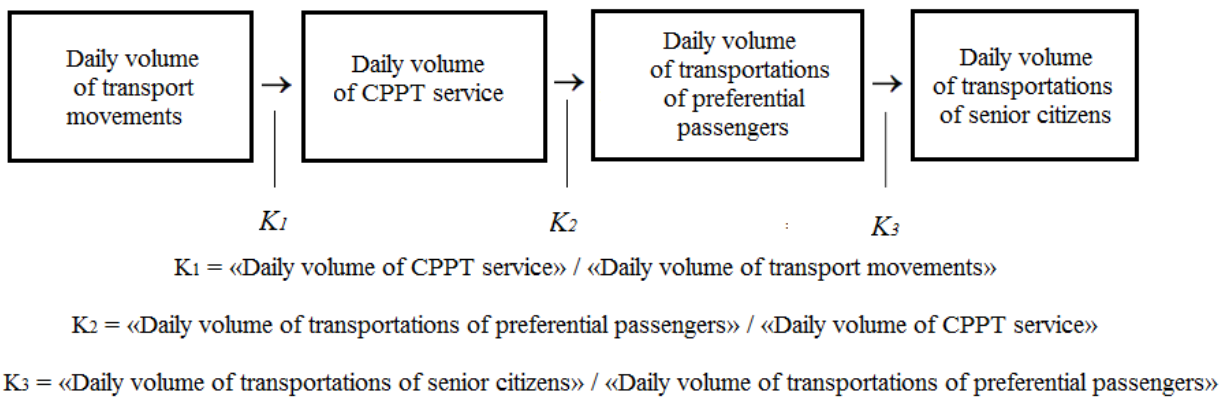

Fig. 1. Three-units process of informational transformation during CPPT process (from the position of management of transportations volume structure).

Choice of such characteristics as «Daily volume of transport movements», «Daily volume of CPPT service», «Daily volume of transportations of preferential passengers», «Daily volume of transportations of senior citizens» allows to estimate structural peculiarities of transformation of volume of CPPT transportation service by attribute «passengers qualitative composition».

Set of transport process characteristics, used for building the cause-and-effect chain, can flexibly change depending on research goals.

Every unit of informational transformation process forms operator - reducing coefficient $K_{i}$, characterizing relative decrease of number of citizens corresponding to every unit of chain $[11,12,13]$. For example, 1,6 million daily transport movements of Tyumen citizens include nearly $400 \ldots 450$ thousand CPPT movements (in the period of «selfisolation» value decreased to $100 \ldots 150$ thousand movements). The share of preferential passengers in CPPT movements is nearly $45 \ldots .55 \%$. The share of senior citizens in preferential passengers is nearly $35 \ldots 50 \%$.

On every subsequent unit of process of informational transformation of volume and CPPT passengers' composition structure of CPPT users changes and it makes an impact on formation of information entropy as characteristic of orderliness of transport service of large city.

\subsection{Method of determination of relative entropy of CPPT transportation process}

Method of determination of relative entropy of CPPT transportation process can be presented as an algorithm. The most important stage of method is determination of priorities of process units in formation of transportation process result.

This problem can be solved by usage of Pareto-analysis $[11,12]$. Preliminarily we need to:

- give definition of process's positive;

- choose necessary metric;

- prepare statistical data.

As for first problem the bigger transfer coefficient of unit $K_{i}$ (i.e. the less information lost during the transfer process in cause-and-effect chain), the more positive result.

Next step we need to measure positive, i.e. choose necessary metric. It can be measured by indicator of positive of researched process $Q$. Positive for particular unit of process is defined as $Q_{i}$ : 


$$
Q_{i}=-\ln \left(K_{i}\right)
$$

If $K_{i}<1$, then decrease of transfer coefficient of unit leads to growth of positive $Q_{i}$.

$$
Q=Q_{1}+Q_{2}+Q_{3}=\sum_{i=1}^{3}\left[-\ln \left(K_{i}\right)\right]
$$

To solve problem of preparing statistical data, we need to do two things. Firstly, connect $K_{i}$ with indicators, used in three-units process of informational transformation (fig. 1). Secondly, determine contribution of every $K_{i}$ to general positive by usage of weight coefficients $w_{i}$.

$$
w_{i}=\frac{Q_{i}}{Q}=\frac{-\ln \left(K_{i}\right)}{\sum_{i=1}^{3}\left[-\ln \left(K_{i}\right]\right.}
$$

Weight coefficients $w_{i}$ should meet conditions of normalization (4):

$$
\sum_{i=1}^{3} w_{i}=1
$$

Structure of weight coefficients $w_{i}$ determines level of transportation process orderliness. Entropy $H$ is its numeric characteristic [3, 4]:

$$
H=-\sum_{i=1}^{n=3} w_{i} \cdot \ln w_{i},
$$

where $\quad n \quad-$ number of units in system (in our case $n=3$ );

$w_{i} \quad-$ weight coefficients meeting conditions of normalization (4).

Entropy $H$ is a functional of structural state of researched process. For comfortable interpretations of results, it's better to use relative entropy $H_{n}$ [11]:

$$
H_{n}=H / H_{\max }=H / \ln (3)
$$

Here and further relative entropy calculated for three-units information transformation process will be denoted as $\left(H_{n}-3\right)$.

Entropy $H_{n}$ and relative entropy $\left(H_{n}-3\right)$ are characteristics of system's disorganization. We need to calculate value of negentropy $\left(1-\left(H_{n}-3\right)\right)$.

According to E. Schrödinger [14, 15], informational entropy is a measure of disorganization of system of any nature. It ranges from maximal entropy $\left(H_{n}=1\right)$, i.e. chaos and full uncertainty, to entropy disappearance $\left(H_{n}=0\right)$, i.e. the highest level of orderliness. In other words, entropy is a measure of disorder $\left(H_{n}=1\right)$, when information $J$ is a measure of orderliness. One equal to other but with different sign.

$$
H+J=1
$$

where $H-$ system entropy;

$J \quad-$ information about system.

E. Schrödinger [14] introduced concept of «negentropy», i.e. «reversed entropy». Relative entropy (in our case случае $(1-(H n-3)))$ is an objective characteristic of system's orderliness. 


\section{Data and results of calculation of entropy $H$ and relative entropy $\left(H_{n-3}\right)$ of Tyumen CPPT system during March- September 2020}

Target task was solved for CPPT system of Tyumen (large city of Russian Federation with population of nearly 810 thousand people as of 2020) on the basis of data of municipal Department of road infrastructure and transport [16].

Range of values of time series of relative entropy $\left(H_{n}-3\right)$ during March...September 2020 (table 1) should be considered with regard to change of external situation.

Table 1. Structuring of research period in accordance to management actions of limiting mobility of Tyumen population.

\begin{tabular}{|c|c|c|c|}
\hline Period dates & Period nature & $\begin{array}{c}\text { Management } \\
\text { actions of limiting } \\
\text { of transport } \\
\text { mobility }\end{array}$ & $\begin{array}{l}\text { Dynamics of } \\
\text { change of }\left(H_{n-}\right. \\
\text { 3) on weekdays }\end{array}$ \\
\hline \multicolumn{4}{|c|}{ Period of gradual decline of epidemiological situation } \\
\hline $1.03 .2020 \ldots 27.03 .2020$ & $\begin{array}{l}\text { Gradual decline of } \\
\text { epidemiological } \\
\text { situation }\end{array}$ & No actions & $\begin{array}{c}\left(H_{n-3}\right) \approx \\
0.92 \ldots 0.98 \text { in the } \\
\text { period before start } \\
\text { of pandemic } \\
\text { COVID-19 }\end{array}$ \\
\hline \multicolumn{4}{|c|}{ Period of acute phase of COVID-19 } \\
\hline $28.03 .2020 \ldots 30.04 .2020$ & $\begin{array}{l}\text { Acute phase of } \\
\text { pandemic }-1 \\
\text { subperiod }\end{array}$ & $\begin{array}{l}\text { Full prohibition of } \\
\text { CPPT service for } \\
\text { senior citizens }(65+) \text {. } \\
\text { Significant part of } \\
\text { population starts } \\
\text { work remotely. }\end{array}$ & $\begin{array}{c}\text { Decline of }\left(H_{n-3}\right) \\
\text { down to } \approx \\
0.77 \ldots 0.85\end{array}$ \\
\hline $1.05 .2020 \ldots 31.05 .2020$ & $\begin{array}{l}\text { Acute phase of } \\
\text { pandemic }-2 \\
\text { subperiod }\end{array}$ & $\begin{array}{l}\text { Lifting the ban on } \\
\text { CPPT service for } \\
\text { senior citizens }(65+) \text {. } \\
\text { Population is } \\
\text { motivated to increase } \\
\text { transport mobility. }\end{array}$ & $\begin{array}{c}\text { Insignificant } \\
\text { increase of }\left(H_{n}-3\right) \\
\text { up to } \approx 0.85 \ldots 0.88\end{array}$ \\
\hline $1.06 .2020 \ldots 30.06 .2020$ & $\begin{array}{l}\text { Acute phase of } \\
\text { pandemic }-3 \\
\text { subperiod }\end{array}$ & $\begin{array}{l}\text { Gradual removing of } \\
\text { COVID-19 } \\
\text { restrictions }\end{array}$ & $\begin{array}{c}\text { Sharp return of } \\
\left(H_{n}-3\right) \text { in the } \\
\text { beginning of June } \\
\text { to } 0.83 \text { and } \\
\text { gradual growth } \\
\text { during June up to } \\
0.89\end{array}$ \\
\hline \multicolumn{4}{|c|}{ Period of lifting regime of hard «self-isolation» of Tyumen CPPT system } \\
\hline $1.07 .2020 \ldots 30.09 .2020$ & $\begin{array}{c}\text { Gradual } \\
\text { improvement of } \\
\text { epidemiological } \\
\text { situation }\end{array}$ & $\begin{array}{l}\text { Almost full removing } \\
\text { of restrictions and } \\
\text { return to usual life } \\
\text { style of population }\end{array}$ & $\begin{array}{c}\text { Insignificant } \\
\text { increase of }\left(H_{n}-3\right) \\
\text { up to } \approx 0.92\end{array}$ \\
\hline
\end{tabular}

The range can be divided into three periods: period of gradual decline of epidemiological situation (1.03.2020...27.03.2020); period of acute phase of COVID-19 and «self-isolation» $(28.03 .2020 \ldots 30.06 .2020)$ and period of gradual return to usual life style of population $(1.07 .2020 \ldots 30.09 .2020)$.

Second period (28.03.2020...30.06.2020) - period of acute phase of COVID-19 - can be also divided into three subperiods: «hard self-isolation» regime 
(28.03.2020...30.04.2020), regime of gradual weakening of «self-isolation» $(1.05 .2020 \ldots 31.05 .2020)$ and period of partial removing of «self-isolation» regime $(1.06 .2020 \ldots 30.06 .2020)$.

To estimate dynamics of orderliness of transport service for Tyumen population in time we need to use time series of values of $\left(H_{n}-3\right)$ calculated by presented above methodic.

Example of calculation of $H$ and $\left(H_{n}-3\right)$ values for CPPT system of Tyumen in period $1.03 .2020 \ldots .7 .03 .2020$ is presented in tables $2 \ldots 4$.

Table 2. Example of initial data (Tyumen CPPT system, beginning of March 2020).

\begin{tabular}{|c|c|c|c|c|c|c|c|}
\hline Date & $\begin{array}{c}\text { Qdaily } \\
\text { city } \\
\text { transport } \\
\text { movemen } \\
\text { ts }\end{array}$ & $\begin{array}{c}\text { Qdaily CPPT } \\
\text { transportatio } \\
\text { ns }\end{array}$ & $\begin{array}{c}\text { Qdaily } \\
\text { number of } \\
\text { transportatio } \\
\text { ns of } \\
\text { preferential } \\
\text { passengers }\end{array}$ & $\begin{array}{c}\text { Qdaily } \\
\text { number of } \\
\text { transportatio } \\
\text { ns of senior } \\
\text { citizens }\end{array}$ & K1 & K2 & K3 \\
\hline $\begin{array}{c}1.03 .202 \\
0\end{array}$ & 1215000 & 242535 & 110109 & 40189 & $\begin{array}{c}0.20 \\
0\end{array}$ & $\begin{array}{c}0.45 \\
4\end{array}$ & $\begin{array}{c}0.36 \\
5\end{array}$ \\
\hline $\begin{array}{c}2.03 .202 \\
0\end{array}$ & 1620000 & 443485 & 201567 & 72614 & $\begin{array}{c}0.27 \\
4\end{array}$ & $\begin{array}{c}0.45 \\
5\end{array}$ & $\begin{array}{c}0.36 \\
0\end{array}$ \\
\hline $\begin{array}{c}3.03 .202 \\
0\end{array}$ & 1620000 & 450089 & 204738 & 74587 & $\begin{array}{c}0.27 \\
8\end{array}$ & $\begin{array}{c}0.45 \\
5\end{array}$ & $\begin{array}{c}0.36 \\
4\end{array}$ \\
\hline $\begin{array}{c}4.03 .202 \\
0\end{array}$ & 1620000 & 453245 & 205623 & 75349 & $\begin{array}{c}0.28 \\
0\end{array}$ & $\begin{array}{c}0.45 \\
4\end{array}$ & $\begin{array}{c}0.36 \\
6\end{array}$ \\
\hline $\begin{array}{c}5.03 .202 \\
0\end{array}$ & 1620000 & 458665 & 207428 & 75711 & $\begin{array}{c}0.28 \\
3\end{array}$ & $\begin{array}{c}0.45 \\
2\end{array}$ & $\begin{array}{c}0.36 \\
5\end{array}$ \\
\hline $\begin{array}{c}6.03 .202 \\
0\end{array}$ & 1620000 & 454535 & 205347 & 74865 & $\begin{array}{c}0.28 \\
1\end{array}$ & $\begin{array}{c}0.45 \\
2\end{array}$ & $\begin{array}{c}0.36 \\
5\end{array}$ \\
\hline $\begin{array}{c}7.03 .202 \\
0\end{array}$ & 1215000 & 296787 & 137653 & 50119 & $\begin{array}{c}0.24 \\
4\end{array}$ & $\begin{array}{c}0.46 \\
4\end{array}$ & $\begin{array}{c}0.36 \\
4\end{array}$ \\
\hline
\end{tabular}

Table 3 presents results of calculation of positive of units of transport process of CPPT $\mathrm{Q}$ and values of weight coefficients $w_{i}$ (for period 1.03.2020 ... 7.03.2020).

Table 4 presents final results of calculation of entropy $H$ and relative entropy $\left(H_{n}-3\right)$ of transport process of CPPT of Tyumen in the first week of March 2020.

Processing of corresponding statistical data produced time series of values of relative entropy $\left(H_{n}-3\right)$ and relative negentropy $\left(1-\left(H_{n}-3\right)\right)$ of transport process of CPPT of Tyumen in period 1.03.2020 ... 30.09.2020 presented on fig. 2 and fig. 3.

Table 3. Result of calculation of positive of units of transport process of Tyumen CPPT system $Q_{i}$ and values of weight coefficients $w_{i}$.

\begin{tabular}{|c|c|c|c|c|c|c|c|c|}
\hline Date & $\boldsymbol{Q}_{\boldsymbol{I}}$ & $\boldsymbol{Q}_{\mathbf{2}}$ & $\boldsymbol{Q}_{3}$ & $\boldsymbol{Q}$ & $w_{1}$ & $w_{2}$ & $w_{3}$ & $\sum_{i=1}^{3} w_{i}$ \\
\hline 1.03 .2020 & 1.611 & 0.790 & 1.008 & 3.409 & 0.473 & 0.232 & 0.296 & 1.000 \\
\hline 2.03 .2020 & 1.296 & 0.789 & 1.021 & 3.105 & 0.417 & 0.254 & 0.329 & 1.000 \\
\hline 3.03 .2020 & 1.281 & 0.788 & 1.010 & 3.078 & 0.416 & 0.256 & 0.328 & 1.000 \\
\hline 4.03 .2020 & 1.274 & 0.790 & 1.004 & 3.068 & 0.415 & 0.258 & 0.327 & 1.000 \\
\hline 5.03 .2020 & 1.262 & 0.794 & 1.008 & 3.063 & 0.412 & 0.259 & 0.329 & 1.000 \\
\hline 6.03 .2020 & 1.271 & 0.795 & 1.009 & 3.074 & 0.413 & 0.258 & 0.328 & 1.000 \\
\hline 7.03 .2020 & 1.409 & 0.768 & 1.010 & 3.188 & 0.442 & 0.241 & 0.317 & 1.000 \\
\hline
\end{tabular}


Table 4. Final results of calculation of entropy $H$ and relative entropy $\left(H_{n}-3\right)$ of transport process of Tyumen CPPT system.

\begin{tabular}{|c|c|c|c|c|c|}
\hline Date & $\left(w_{1} \cdot \ln w_{1}\right)$ & $\left(w_{2} \cdot \ln w_{2}\right)$ & $\left(w_{3} \cdot \ln w_{3}\right)$ & $H=-\sum_{i=1}^{n=3} w_{i} \cdot \ln w_{i}$ & $\left(\boldsymbol{H}_{\boldsymbol{n}} \mathbf{3}\right)$ \\
\hline 1.03 .2020 & -0.354 & -0.339 & -0.360 & 1.0533 & 0.9587 \\
\hline 2.03 .2020 & -0.365 & -0.348 & -0.366 & 1.0785 & 0.9817 \\
\hline 3.03 .2020 & -0.365 & -0.349 & -0.366 & 1.0793 & 0.9824 \\
\hline 4.03 .2020 & -0.365 & -0.349 & -0.366 & 1.0799 & 0.9830 \\
\hline 5.03 .2020 & -0.365 & -0.350 & -0.366 & 1.0810 & 0.9840 \\
\hline 6.03 .2020 & -0.365 & -0.350 & -0.366 & 1.0805 & 0.9835 \\
\hline 7.03 .2020 & -0.361 & -0.343 & -0.364 & 1.0679 & 0.9721 \\
\hline
\end{tabular}

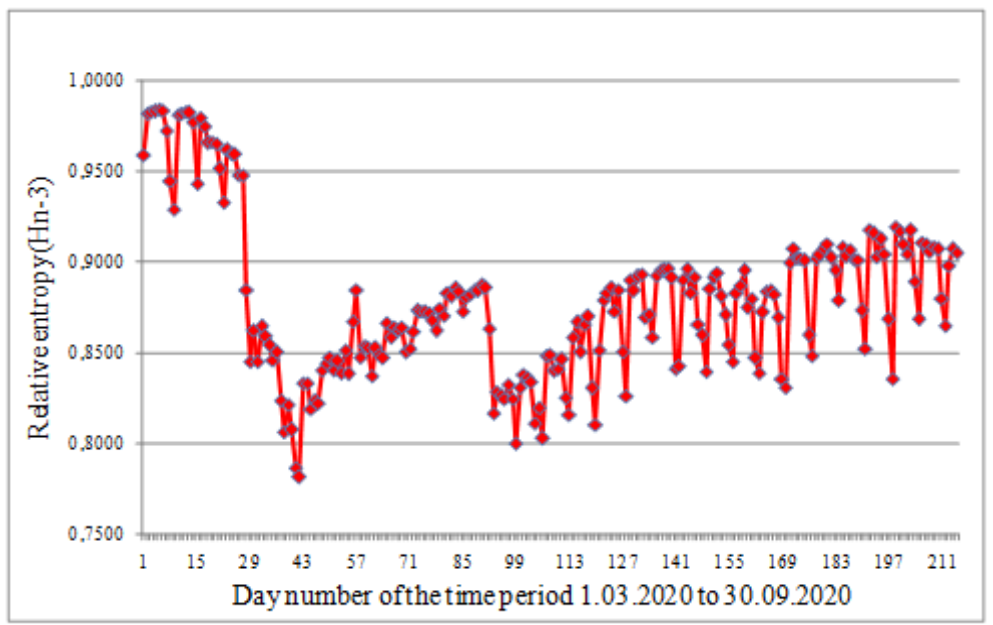

Fig. 2. Time series of values of relative entropy $(\mathrm{Hn} n-3)$ of transport process of Tyumen CPPT system in period 1.03.2020 ... 30.09.2020.

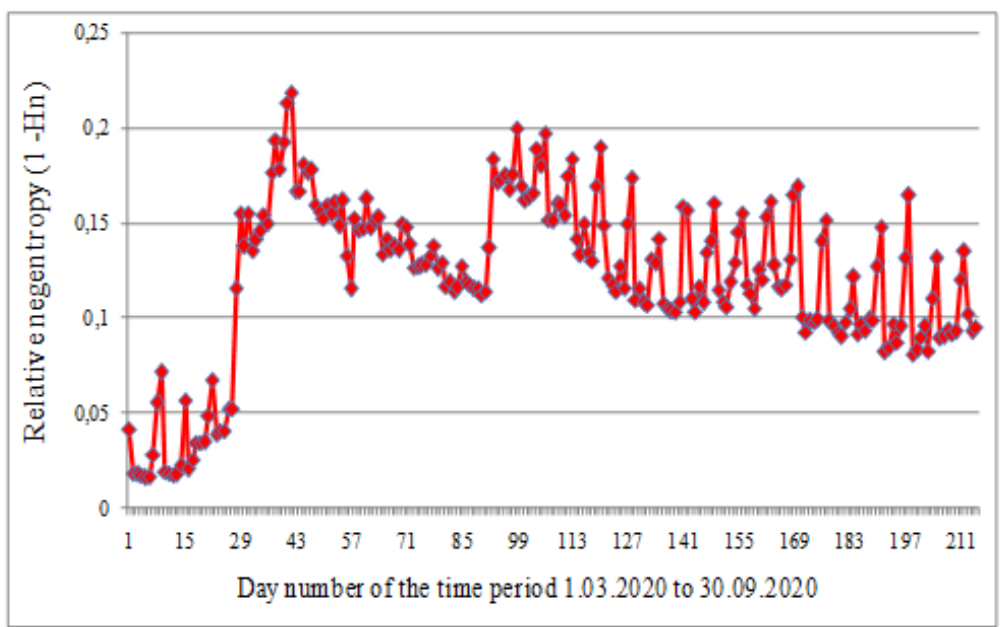

Fig. 3. Time series of values of relative negentropy $\left(1-\left(H_{n}-3\right)\right)$ of transport process of Tyumen CPPT system in period 1.03.2020 ... 30.09.2020. 


\section{Discussion and analysis of results}

In usual conditions of CPPT system functioning (weekdays), typical for the beginning of March 2020, 1250 buses were in service, daily volume of Tyumen CPPT system transportations $Q$ daily was 450 thousand people. In this period relative entropy $\left(H_{n}-3\right)$, as indicator of disorder of transportation process, was in range [0.95; 0.98].

During the period of «hard self-isolation» mobility of city population, especially senior citizens, was significantly limited. Relative entropy $\left(H_{n}-3\right)$ of transport process of CPPT significantly decreased down to $[0.77 ; 0.85]$ and it reached $0.77 \ldots 0.78$ in several days of April 2020. In May 2020 this indicator insignificantly increased up to $0.85 \ldots 0.88$.

Change of level of transportation process orderliness formed intermittently. It happened this way because of sharp amplification or weakening of «self-isolation» measures and change of transport service organization system according to these administrative measures (fig. 4...5).

State of Tyumen CPPT system during 3 subperiods of acute phase of pandemic (1.06.2020 ..30.06.2020) can be characterized as regime of search of new sustainable form.

Since 1.06.2020 CPPT have come back to almost original work mode. The number of performed routes was stable during June-September 2020: on weekdays $\approx 11500$ per day, on Saturday $\approx 9000$ per day, on Sunday $\approx 8500$ per day. Daily volume of transportations increased and varied in range from 270 to 350 thousand passengers per day.

Relative entropy $\left(\mathrm{H}_{n}-3\right)$ of transportation process in June varied in range $[0.85 ; 0.88]$, in July-September $2020\left(H_{n}-3\right) \approx 0.89 \ldots 0.92$.

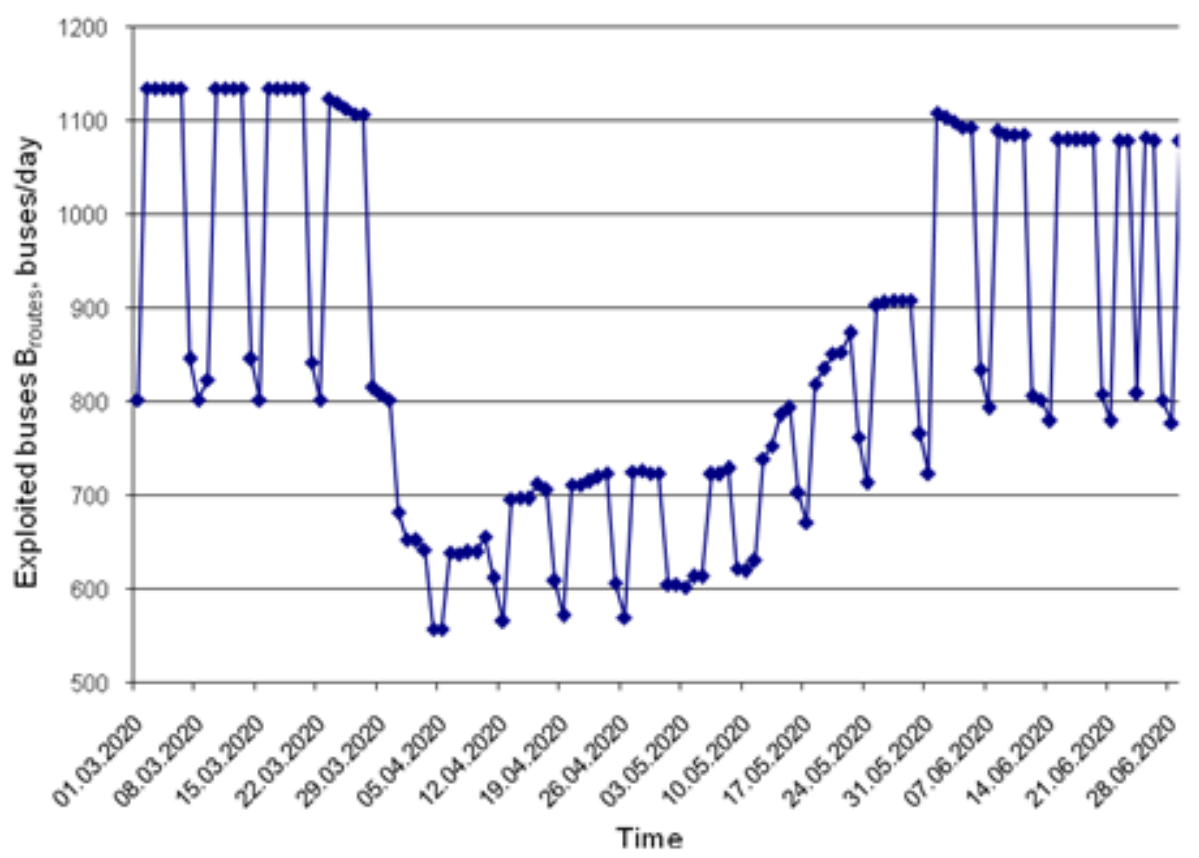

Fig. 4. Diagram of change of number of buses, exploited at Tyumen CPPT routes in period 1.03.2020 ... 30.06.2020. 


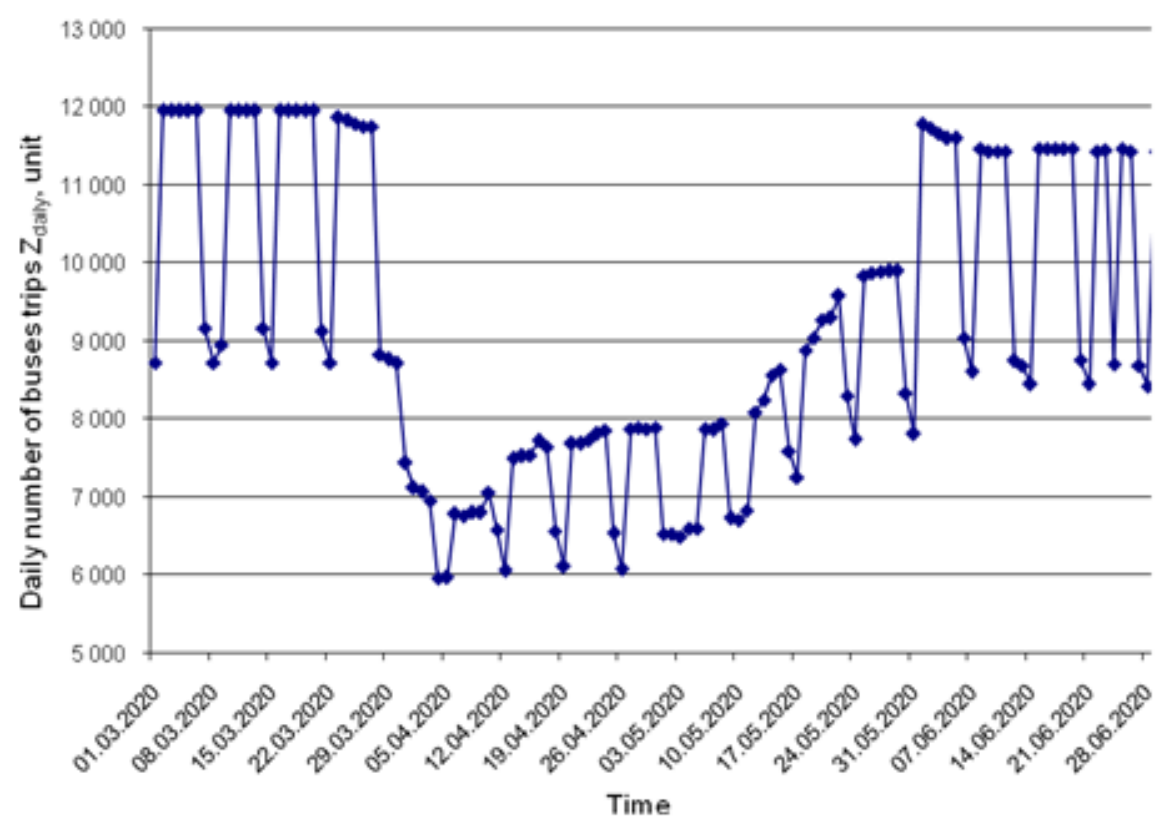

Fig. 5. Diagram of change of executed buses trips on Tyumen CPPT routes in period $1.03 .2020 \ldots$ 30.06.2020.

\section{Conclusions}

Analysis allows to make next important conclusions.

- Orderliness of transportation process of Tyumen CPPT system during March September 2020 significantly changed. Range of values of orderliness characteristics varied in this period: relative entropy $(\mathrm{Hn}-3)$ was $\approx 0.77 \ldots 0.98$, relative negentropy $(1-(\mathrm{Hn}-3))$ was $\approx 0.02 \ldots 0.23$.

- Wide range of (Hn-3) and (1 - (Hn-3)) of transportation process in March September 2020 is explained by significant dynamic changes of structure of volume of passengers in Tyumen (total volume of transportations - volume of transportations of preferential passengers - volume of transportations of senior citizens).

- At weekends relative entropy (Hn-3) of transportation process is lower than on weekdays. It can be explained by increase of senior citizens share in volume of transportations in comparison to weekends.

Recommendations on possible increase of transportation process orderliness (i.e. decrease of $\left.\left(H_{n}-3\right)\right)$ in periods of stable functioning of CPPT system are based on optimization of structural composition of transported passengers. The bigger share of preferential passengers, the lower values of relative entropy $\left(H_{n}-3\right)$. It is explained by the fact that preferential passengers and their repeated in time transport behavior is factor stabilizing demand in CPPT service. They are regular users of CPPT service on specific routes in specific time. Preferential passengers steady CPPT system in relation to demand formation.

Hypothetical calculations by this methodic show that theoretically it's possible to reach value of relative entropy $\left(\mathrm{H}_{\mathrm{n}}-3\right)$ of transportation service of Tyumen population nearly equal to 0,382 which corresponds to relative negentropy $\left(1-\left(H_{n}-3\right)\right)$ nearly equal to 0.618 
(table 5). It provides harmonious (according to «golden ratio» [17]) level of orderliness of transport service of large city population.

Table 5. Hypothetical example of initial data providing harmonious (according to golden ratio $\left(H_{n}-3\right)$ $\approx 0.382$ ) level of orderliness of transport service of large city population.

\begin{tabular}{|c|c|c|c|c|c|c|c|}
\hline Date & $\begin{array}{l}Q_{\text {daily city }} \\
\text { transport } \\
\text { movements }\end{array}$ & $\begin{array}{c}Q_{\text {daily }} \text { CPPT } \\
\text { transportations }\end{array}$ & $\begin{array}{c}Q_{\text {daily number }} \\
\text { of } \\
\text { transportations } \\
\text { of preferential } \\
\text { passengers }\end{array}$ & $\begin{array}{c}Q_{\text {daily number }} \\
\text { of } \\
\text { transportations } \\
\text { of senior } \\
\text { citizens }\end{array}$ & $K_{1}$ & $K_{2}$ & $\boldsymbol{K}_{3}$ \\
\hline \multicolumn{8}{|c|}{1 option of data combination } \\
\hline Abstract & 1620000 & 1503000 & 1477000 & 738500 & 0.928 & 0.983 & 0.5 \\
\hline \multicolumn{8}{|c|}{2 option of data combination } \\
\hline Abstract & 1620000 & 1385100 & 1361550 & 408465 & 0.855 & 0.983 & 0.3 \\
\hline \multicolumn{8}{|c|}{$\begin{array}{c}\text { Note. Structure of volume of transported passengers, i.e. combination of initial data and calculated } \\
\text { values of coefficients Ki can change but continue to provide necessary level of orderliness of } \\
\text { transportation process }\left(\left(1-\left(\mathrm{H}_{n}-3\right)\right) \approx 0.618\right)\end{array}$} \\
\hline
\end{tabular}

Widening of share of preferential passengers in total volume of transportations allows to significantly increase volume of CPPT transportations. It means to change trajectory of development of city transport system from ideology of individual automobilization (IAT), which didn't acquit itself in majority number of countries with not high level of specific GDP $[18,19]$, to approaches of top-priority development of CPPT. This way is possible if owners of personal vehicles start to ride on public transport. Redirection of part of means from development of IAT to development of CPPT could allow to transfer all passengers to preferential category. Such way of development of transport systems was considered in USSR in 1970-1980 but then it was admitted as inadvisable according to economic reasons [20].

Today chaos in CPPT system functioning is created by passengers who use CPPT service unstably. Usually they are passengers without any privileges for pay for transport. Possibility of transportations of unstable passengers varies. It makes a chaos impact on transport process and formation of transportations volume. Perhaps that is why head managers of transport industry of Russian Federation think about possibility of introduction of fully free city public transport since 2035 [21]. Implementation of this idea could significantly increase level of orderliness of public transport system.

Probably soon this option of transport service system development will be not only possible but also the only correct one from the position of transport process orderliness increase.

\section{Reference}

1. N. Wiener, Cybernetics: Or Control and Communication in the Animal and the Machine, 2nd revised ed., Paris: Hermann \& Cie, Camb. Mass., (1961).

2. N. Wiener, Perspectives in Cybernetics, Progress in Brain Research, 17(C), 399-415, (1965).

3. C.E. Shannon, A Mathematical Theory of Communiation, Bell System Technical Journal, Vol. 27, 379-423, (1948).

4. C.E. Shannon, Collected Papers, edited by N.J.A Sloane and A.D. Wyner, IEEE press, (1993).

5. L. Brillouin, Science and information theory, New York, Acad. press publ., (1956). 
6. A. J. Wilson, Entropic methods of modelling of complex systems, (in Russian), Moscow, (1978).

7. A.G. Wilson, The Use of the Concept of Entropy in System Modelling, J Oper Res Soc 21, 247-265, (1970).

8. P. Chambadal, Evolution et Applications du Concept D'Entropie, Dunod, Paris, (1963).

9. S.L. Demenok, Simply entropy, (in Russian), S.-Pb., Strata, (2018).

10. O.V. Tsvetkov, Entropy analysis of data in physics, biology and engineering, (in Russian), S.-Pb., Publ. house of SPbGETU "LETI", (2015).

11. V. Kolesov, A. Petrov, Cybernetic modeling in tasks of traffic safety management, Transportation Research Procedia, 20, 305-310 (2017).

12. V.I. Kolesov, O.F. Danilov, A.I. Petrov, Specific features of goal setting in road traffic safety, IOP Conf. Series: Earth and Environmental Science, 90, 012059, (2017).

13. A. Petrov, V. Kolesov, Entropic analysis of dynamics of road safety system organization in the largest Russian cities, IOP Conference Series: Earth and Enviromental Science, 177, 012015, (2018).

14. E. Schrödinger, What is Life? The Physical Aspect of the Living Cell, Cambridgeat the University Press, (1944).

15. J. Götschl, Erwin Schrödinger's World View: The Dynamics of Knowledge and Reality, Springer Science \& Business Media (1992).

16. Department of road infrastructure and transport of the Tyumen city Administration. Available from: http://www.tyumen-city.ru/vlast/administration/struktura-administracii -goroda-tumeni/departaments/departament-dorojnoi-infrastrukturi-i-transporta/ [Accessed 8th November 2020].

17. R. Herz-Fischler, A Mathematical History of the Golden Number, Courier Corporation, (2013).

18. D. Acemoglu, J. Robinson, Why Nations Fail: The Origins of Power, Prosperity, and Poverty, Crown Publishers (New York), (2012).

19. T. Vanderbilt, Traffic. Why We Drive the Way We Do (and What It Says About Us), Al. A. Knopf, New York, Toronto, (2008).

20. S.V. Anureev, Clash of theories of budget subsidies, paid public services and fiscal monopoly (on the example of the Moscow metro and in the context of world experience), Accounting in budget and non-profit organizations, 4(484), (2020).

21. The Ministry of transport has proposed to prepare for the free transport and toll roads (in Russian) Available from: https://www.rbc.ru/society/11/09/2020/5f58d4489a 7947771a7c09e1?from=column_1 [Accessed 8th November 2020]. 